\title{
Inhibitory coverage of dendritic excitation
}

\author{
Albert Gidon ${ }^{1 *}$, Idan Segev ${ }^{1,2,3}$ \\ From Twentieth Annual Computational Neuroscience Meeting: CNS*2011 \\ Stockholm, Sweden. 23-28 July 2011
}

"The Coverage Problem" is a class of optimization problems used in different fields that aims to explore the best strategy in order to maximally "cover" a region under some constrains. For example, how could a limited number of cellular antennas be distributed such that their signals would cover a maximal region (e.g., a whole city) while limiting the radio-frequency radiation to safe levels? Here we ask whether the notion of coverage could be applied to inhibitory synapses, giving them optimal control over the excitatory/excitable activity in the dendritic tree. In support of this idea is the fact that most (85\%) [1-3] inhibitory synapses target dendrites rather than operate at the soma/axon region as a global veto mechanism of the neuron's output . Additionally, it seems to be the rule rather than the exception that single inhibitory axons target specific dendritic sub-regions where each axon makes multiple synapses [4-6], implying that the role of such inhibition is to cover a particular dendritic region. Using analytic solutions of the cable theory as well as detailed compartmental models, we searched for the spatial distribution of inhibition that maximally covers the modeled dendrite under different constraints (e.g., fixed number of contacts per axon and fixed total inhibitory conductance). We explored the conditions in which the inhibitory coverage would be most effective in controlling the neuronal output and compared our results to the actual distributions of inhibitory synapses in different dendrites. We showed that despite the small number of inhibitory synapses (relative to the excitatory synapses) in dendrites of most central neurons, when the synapses are strategically placed, they can effectively dampen the excitatory/excitability activity in dendrites both globally and in a domain-specific manner.

\section{Author details}

${ }^{1}$ Department of Neurobiology, The Hebrew University of Jerusalem, Israel. ${ }^{2}$ Interdisciplinary Center for Neural Computation, The Hebrew University of Jerusalem, Israel. ${ }^{3}$ Edmond and Lily Safra Center for Brain Sciences, The Hebrew University of Jerusalem, Israel.

Published: 18 July 2011

References

1. Beaulieu C, Kisvarday Z, Somogyi P, Cynader M, Cowey A: Quantitative distribution of GABA-immunopositive and -immunonegative neurons and synapses in the monkey striate cortex (area 17). Cereb. Cortex 1992, 2:295-309

2. Beaulieu C, Somogyi P: Targets and Quantitative Distribution of GABAergic Synapses in the Visual Cortex of the Cat. Eur. J. Neurosci 1990, 2:296-303.

3. Liu G: Local structural balance and functional interaction of excitatory and inhibitory synapses in hippocampal dendrites. Nat. Neurosci 2004, 7:373-379.

4. Markram H, Toledo-Rodriguez M, Wang Y, Gupta A, Silberberg G, Wu C: Interneurons of the neocortical inhibitory system. Nat. Rev. Neurosci 2004, 5:793-807

5. Klausberger T, Somogyi P: Neuronal diversity and temporal dynamics: the unity of hippocampal circuit operations. Science 2008, 321:53-57.

6. Douglas RJ, Martin KA: Inhibition in cortical circuits. Curr. Biol 2009, 19 : R398-402.

doi:10.1186/1471-2202-12-S1-P291

Cite this article as: Gidon and Segev: Inhibitory coverage of dendritic excitation. BMC Neuroscience 2011 12(Suppl 1):P291.

* Correspondence: agidon20@gmail.com

${ }^{1}$ Department of Neurobiology, The Hebrew University of Jerusalem, Israel

Full list of author information is available at the end of the article

Submit your next manuscript to BioMed Central and take full advantage of:

- Convenient online submission

- Thorough peer review

- No space constraints or color figure charges

- Immediate publication on acceptance

- Inclusion in PubMed, CAS, Scopus and Google Scholar

- Research which is freely available for redistribution

Submit your manuscript at www.biomedcentral.com/submit
() Biomed Central
C Biomed Central

(c) 2011 Gidon and Segev; licensee BioMed Central Ltd. This is an open access article distributed under the terms of the Creative Commons Attribution License (http://creativecommons.org/licenses/by/2.0), which permits unrestricted use, distribution, and reproduction in any medium, provided the original work is properly cited. 